\title{
DISTRIBUTION AND CLINICOPATHOLOGICAL FEATURES OF BREAST CANCER HISTOLOGICAL SUBTYPES IN LATVIA
}

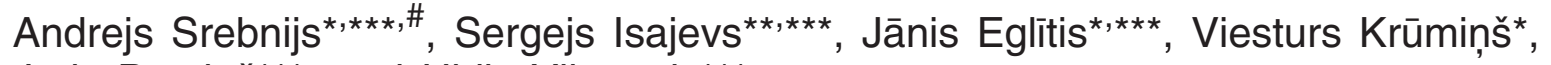 \\ Juris Bērziṇš ${ }^{* * *}$, and Uldis Vikmanis*** \\ * Latvian Oncology Centre, Rīga East Clinical University Hospital, Hipokrāta iela 4, Rīga, LV-1079, LATVIA; \\ srebnijs@apollo.Iv; andrejs.srebnijs@ aslimnica.Iv \\ ** Centre of Pathology, Rīga East Clinical University Hospital, Hipokrāta iela 4, Rīga, LV-1079, LATVIA \\ ${ }^{* * *}$ Faculty of Medicine, University of Latvia, Šarlotes iela 1a, Rĩga, LV-1001, LATVIA \\ \# Corresponding author
}

Communicated by Vija Kluša

\begin{abstract}
Breast cancer is a heterogenous disease. It consists of several histological subtypes that can be separated by morphology and immunohistochemistry. The aim of our study was to determine the distribution of breast cancer histological and molecular subtypes, and their relationship with clinical and pathological characteristics. A total of 561 patients who underwent breast carcinoma surgical treatment from January 2003 till December 2012 were enrolled in the study. In total, invasive ductal carcinomas not otherwise specified (IDC-NOS) plus invasive ductal carcinomas no special type (IDC-NST) were observed in 430 patients (76.65\% of cases), medullar carcinoma in 14 patients (2.45\%), other rare ductal carcinoma subtypes in 13 patients (2.31\%), lobular carcinoma in 81 patients (14.4\%) and tubulolobular carcinoma in 23 patients (4.19\%). Ductal carcinoma, lobular and tubulolobular carcinoma had predominantly luminal $A$ and $B$ subtype, whereas medullar carcinoma had HER2- positive and triple-negative (TN) subtype. Tubular, cribriform, mucinous, papillary, and apocrine carcinomas had predominantly luminal $A$ subtype. Significant differences between breast cancer histological subtypes and clinicopathological characteristics were observed. Our study for the first time reported the distribution and characteristics of breast cancer histological subtypes in Latvian women and relationship to clinical and tumour histopathological characteristics.
\end{abstract}

Key words: breast cancer, histological subtypes, molecular subtypes, clinicopathological characteristics.

\section{INTRODUCTION}

Breast cancer is a heterogeneous disease, composing numerous distinct entities that have different clinical presentations, aggressiveness, response to treatments, and outcomes among different groups of patients with breast cancer or ethnic populations (Perou et al., 2000). In Latvia, there are over 1000 new breast cancer cases per year. In the period of the last 30 years the incidence of breast cancer in Latvia has more than doubled (from 461 cases in 1978 to 1056 cases in 2008) and is continuing to increase (1245 new cases in 2011) and the mortality rate has increased by 103.4\% (from 231 in 1978 to 470 in 2008) (Srebnij et al., 2011).

Invasive breast cancers are a heterogeneous group of tumours that show wide variation with regard to their clinical presentation, behaviour, and morphological spectrum. At least 20 different histological breast cancer types (i.e. patho- logical entities) are described by the World Health Organization (WHO) (Lakhanie et al., 2012).

Invasive ductal carcinoma not otherwise specified (IDC NOS) accounts for the large majority of breast cancers, i.e. $50-80 \%$ (Weigelt et al., 2008). IDC NOS is a diagnosis by default, being defined by the WHO as a tumour that fails to exhibit sufficient morphological characteristics to be classified into one of the histological special types (Lakhanie et al., 2012). Approximately $25 \%$ of invasive breast cancers are recognised as "special types", and characterised by distinctive growth patterns and cytological features (Weigelt et al., 2010).

The most common subtypes are lobular carcinoma, tubulolobular carcinoma, medullary carcinoma, invasive tubular carcinoma, invasive cribriforme carcinoma, invasive papillary carcinoma, invasive apocrine carcinoma, adenoid cystic carcinoma, mucinous carcinoma, neuroendocrina car- 
cinoma, metaplastic carcinoma and others (Lakhanie et al., 2012; Caldarella et al., 2013; Montagna et al., 2013).

Breast cancers can be classified into biologically and clinically meaningful subgroups according to histological grade and histological type. Grade is an assessment of the degree of differentiation (i.e. tubule formation and nuclear pleomorphism) and proliferative activity (i.e. mitotic index) of a tumour, and mirrors its aggressiveness. Interestingly, grade has been shown to be correlated with the genetic and transcriptomic features of breast cancers and microarray-based genomic signatures for histological grade have been devised (Desmedt et al., 2006; Weigelt et al., 2010). Histological type, on the other hand, refers to the growth pattern of the tumours (Lips et al., 2013).

In the past decade, high throughput microarray-based gene expression profiling has been extensively applied to the study of breast cancer to unravel the molecular underpinning of biological features such as metastatic propensity (Chekhun et al., 2013; Ciriello et al., 2013). The molecular profiling of breast cancer very rapidly developed at the beginning of this century, together with sophisticated technologies, such as DNA microarrays.

Studies using gene expression arrays have classified breast cancer into at least eight intrinsic subtypes: Luminal A and $\mathrm{B}$, human epidermal growth factor receptor-2 (HER2)-enriched and several oestrogen receptor (ER)-negative subtypes, the most important of which are Basal-like and Normal breast-like (Nielsen et al., 2004; Carey et al., 2006). Studies over the last 3-4 years have shown that, using only clinical and pathological criteria, it is possible to assign four main molecular surrogate subtypes that, while not being strictly identical, are very similar to the original subtypes defined by microchip methods (Cadoo et al., 2013).

In March 2011, the St. Gallen Consensus Conference on Early Breast Cancer adopted recommendations for use of surrogate breast cancer subtypes in clinical practice (Table 1, Goldhirsch et al., 2011).

Although many studies have examined correlation between common breast cancer risk factors, race and hormone receptor status, only a few studies have investigated the correlation between histological and molecular subtypes of tumours and their clinicopathological characteristics. However, recently, evidence has accumulated to support the notion that breast cancer histological and molecular subtypes are distributed in specific patterns corresponding to race or ethnicity (Goldrich et al., 2011). Therefore, the aim of our study was to investigate the distribution and clinicopathologic features of breast cancer histological and molecular subtypes in Latvia.

\section{MATERIALS AND METHODS}

Patients. A total of 561 patients aged 27 to 89 years who underwent breast carcinoma surgical treatment from January 2003 till December 2012 at the Latvian Oncology Cen-
SURROGATE BREAST CANCER INTRINSIC SUBTYPES

\begin{tabular}{ll}
\hline \multicolumn{1}{c}{ Subtype } & \multicolumn{1}{c}{ Characteristics } \\
\hline Luminal A & $\begin{array}{l}\text { ER+ and/or PR+, HER2-, low Ki67 and/or } \\
\text { G1-2 }\end{array}$ \\
Luminal B & $\begin{array}{l}\text { ER+ and/or PR+, HER2+ (or HER2- with } \\
\text { high Ki67 and/or G3) }\end{array}$ \\
Triple negative/basal-like & ER-, PR-, HER2- \\
HER2+ & ER-, PR-, HER2+
\end{tabular}

There are four major breast cancer intrinsic subtypes (luminal A, luminal B, HER2-enriched and triple negative). Luminal A tumours are hormone receptors (ER, PR) positive, HER2 negative and have low proliferative (Ki-67 index), whereas luminal B tumours can be HER2 positive or HER2 negative with subsequent high proliferative index. The HER2-enriched subtype is characterised by HER2 protein overexpression, whereas the triple negative subtype does not express ER, PR and HER2.

tre of Rīga East University Hospital were enrolled in the study. All patients were operated by a single surgeon. The exclusion criteria were metastatic disease at diagnosis, without definitive surgery, incomplete medical records and follow-up status, disease-free survival less than three months; unavailable for oestrogen receptor (ER), progesterone receptor (PR) or HER-2 status, and absence of information of both histological grade and Ki-67 expression.

The St Gallen 2011 consensus conference recommended criteria for dividing tumours in four surrogate intrinsic immunohistochemical subtypes were used. Only 3+ HER2 overexpression and ER or PR receptor status greater than $5 \%$ were considered to be positive. A low Ki-67 was considered to be $<15 \%$. All patients were staged according to the American Joint Committee on Cancer (Edge et al., 2010). The study was approved by the Riga East Clinical University Hospital Ethical Committee. The study conformed to the principles of the declaration of Helsinki.

Microscopical examination. Tissue specimens were fixed in formalin and embedded in paraffin and processed routinely. All tissue samples were examined by a pathologist in blinded fashion according to the WHO classification of the breast tumours (Lakhani et al., 2012).

Immunohistochemical analysis. Tissue sections were immunostained to evaluate ER, PR, Ki-67 and E-cadherin expression. The slides were incubated one hour at room temperature with mouse monoclonal ER antibody (clone 1D5, M7047, dilution 1:60 dilution), mouse monoclonal PR antibody (clone PgR636, M3569, dilution 1:50), mouse monoclonal E-cadherin antibody (clone NCH-38, M3612, dilution 1:100) and mouse monoclonal Ki-67 antibody (clone MiB1, M7240, dilution 1:150). The assessment of HER-2 expression was carried out using the Herceptest kit by a qualitative scale score from 0 to $3+$ based on interpretation of staining intensity (Montagna et al., 2013).

Statistical analysis. A two-way ANOVA followed by Bonferonni post-test was used to assess significant differences in pathological and clinical characteristics. The results were 
expressed as mean $\pm \mathrm{SD}$. All statistical tests were twotailed and $p<0.05$ was considered significant. Statistical analysis was performed by SPSS Statistic 20.0 version software (IBM SPSS Statistics).

\section{RESULTS}

All patients were divided into four groups according to breast cancer intrinsic molecular subtypes. Eight different histological subtypes were demonstrated among the study patients. The clinical and histological characteristics of the breast carcinoma are shown in Tables 2-4.

Patient mean age at diagnosis was $58.09 \pm 12.35$ years. Mean tumour size was $2.16 \pm 1.32 \mathrm{~cm}$. The tumour clinical stage on the first diagnosis predominantly was stage I and II. Luminal A and luminal B subtype was more prevalent, followed by triple negative and HER2 subtype.

Most of the tumours $(76.65 \%)$ were diagnosed as invasive ductal carcinomas not otherwise specified (IDC-NOS). The second common histological subtype was lobular carcinoma, which was observed in 81 patients $(14.4 \%)$. Other histological subtypes were observed in $8.95 \%$ of cases: tubulolobular carcinoma in $4.03 \%$, medullar carcinoma in $2.31 \%$, and other rare ductal carcinoma subtypes (tubular, cribriform, mucinous, papillary, apocrine carcinomas) in $2.45 \%$ (Tables 2-4).

Our study demonstrated significant differences between breast cancer histological subtypes in relation to clinicopathological characteristics. Patients with medullar carcinoma were younger, had larger tumour size and high proliferative index (Ki-67 expression), compared to other histological subtypes ( $p<0.001$, Tables 2 and 3). In addition, medullar carcinoma predominantly had negative hormone receptor status and higher rate of sentinel lymph node metastasis, compared to other histological subtypes $(p<0.0001$, Tables $2-4)$.

Patients with other ductal carcinoma histological subtypes had higher median age, smaller tumour size, low proliferative index and was highly differentiated tumours (Grade 1), compared to other groups $(p<0.01$, Tables $2-4)$.

Patients with tubulolobular carcinoma had larger median tumour size and were characterised by higher rate of sentinel lymph node metastasis, compared to other groups $(p<$ 0.001). In addition, patients with tubulolobular carcinoma more frequently underwent radical mastectomy, compared to other groups ( $p<0.01$, Tables $2-4)$.

Patients with lobular carcinoma had the lowest risk of sentinel lymph node metastasis, compared to other groups $(p<$ 0.01 , Tables 2 and 3). Furthermore, the mean age of patients of other ductal carcinoma histological subtypes (tubular, cribriform, mucinous, papillary, apocrine carcinomas) was higher, but tumour size smaller, compared to other groups $(p<0.001$, Tables 2-4).

\section{DISCUSSION}

Our study demonstrated significant differences between the breast cancer histological subtypes in relation to clinicopathological characteristics. Patients with medullar carcinoma were younger, had higher average tumour size and histological grade. Patients with tubular, cribriform, mucinous, papillary, apocrine carcinomas had higher mean age, but smaller average tumour size and low proliferative index, compared to other subtypes. Patients with tubulolobular carcinoma had larger average tumour size and had a higher rate of sentinel lymph node metastasis, compared to other groups. In addition, patients with tubulolobular carcinoma more frequently underwent radical mastectomy, compared

Table 2

CLINICAL CHARACTERISTICS OF BREAST CARCINOMA PATIENTS WITH DIFFERENT HISTOLOGICAL SUBTYPES

\begin{tabular}{|c|c|c|c|c|c|c|c|}
\hline \multicolumn{2}{|c|}{ Variable } & \begin{tabular}{|c} 
Ductal carcinoma, \\
NOS \\
$\mathrm{n}=430$ \\
$(75.17 \%)$ \\
\end{tabular} & $\begin{array}{l}\text { Medullar } \\
\\
\mathrm{n}=14 \\
(2.45 \%)\end{array}$ & \begin{tabular}{|c} 
Others ductal sub- \\
types \\
$\mathrm{n}=13$ \\
$(2.27 \%)$ \\
\end{tabular} & $\begin{array}{l}\text { Lobular } \\
\begin{array}{c}n=81 \\
(14.16 \%)\end{array}\end{array}$ & $\begin{array}{c}\text { Tubulo-lobular } \\
\begin{array}{c}\mathrm{n}=23 \\
(4.03 \%)\end{array}\end{array}$ & $\begin{array}{l}\text { Total } \\
\mathrm{n}=561 \\
(100 \%)\end{array}$ \\
\hline Age (years) & $\begin{array}{l}\text { Mean age, } \\
\text { min-max, } \\
\text { SD }\end{array}$ & $\begin{array}{c}56.59 \\
(27-89) \\
\pm 12.29 \\
\end{array}$ & $\begin{array}{r}52.64^{*} \\
(36-76) \\
\pm 12.04 \\
\end{array}$ & $\begin{array}{c}62.27^{ \pm} \\
(46-76) \\
\pm 9.83 \\
\end{array}$ & $\begin{array}{c}59.82 \\
(33-87) \\
\pm 12.29 \\
\end{array}$ & $\begin{array}{c}59.13^{* *} \\
(44-85) \\
\pm 11.87 \\
\end{array}$ & $\begin{array}{c}58.09 \\
(27-89) \\
( \pm 12.35)\end{array}$ \\
\hline $\begin{array}{l}\text { Tumour size, } \\
\mathrm{cm}\end{array}$ & $\begin{array}{l}\text { Mean, } \\
\text { min-max, } \\
\text { SD } \\
\end{array}$ & $\begin{array}{c}2.14 \\
(0.2-10) \\
\pm 1.32 \\
\end{array}$ & $\begin{array}{l}2.22 * \\
(1-3) \\
\pm 0.69 \\
\end{array}$ & $\begin{array}{c}1.76^{\neq} \\
(0.1-6) \\
\pm 1.57 \\
\end{array}$ & $\begin{array}{c}2.10 \\
(0.4-9) \\
\pm 1.36 \\
\end{array}$ & $\begin{array}{c}2.57 \\
(0.9-6) \\
\pm 1.4 \\
\end{array}$ & $\begin{array}{c}2.16 \\
(0-10) \\
\pm 1.32 \\
\end{array}$ \\
\hline \multicolumn{2}{|c|}{$\begin{array}{l}\text { Positive sentinel lymph node } \\
\text { (n, \% of SN procedure) }\end{array}$} & $\begin{array}{c}26 \\
(18.7 \%) \\
\end{array}$ & $\begin{array}{c}2 \\
(66.6 \%) \\
\end{array}$ & 0 & $\begin{array}{c}4 \\
(17.4 \%) \\
\end{array}$ & $\begin{array}{c}3 \\
(60.0 \%)^{* *} \\
\end{array}$ & $\begin{array}{c}35 \\
(19.0 \%) \\
\end{array}$ \\
\hline \multirow[t]{2}{*}{$\begin{array}{l}\text { Type of surgery, } \\
\text { n (\%) }\end{array}$} & $\begin{array}{l}\text { Breast conserving } \\
\text { surgery (BCS) }\end{array}$ & $\begin{array}{c}202 \\
(47.0 \%) \\
\end{array}$ & $\begin{array}{c}11 \\
(78.6 \%) \\
\end{array}$ & $\begin{array}{c}8 \\
(61.5 \%) \\
\end{array}$ & $\begin{array}{c}39 \\
(48.1 \%) \\
\end{array}$ & $\begin{array}{c}6 \\
(26.1 \%) \\
\end{array}$ & $\begin{array}{c}266 \\
(47.41 \%) \\
\end{array}$ \\
\hline & Mastectomy & $\begin{array}{c}228 \\
(53.0 \%)\end{array}$ & $\begin{array}{c}3 \\
(21.4 \%) \\
\end{array}$ & $\begin{array}{c}5 \\
(38.5 \%) \\
\end{array}$ & $\begin{array}{c}42 \\
(51.9 \%) \\
\end{array}$ & $\begin{array}{c}17 \\
(73.9 \%)^{* *}\end{array}$ & $\begin{array}{c}295 \\
(52.59 \%) \\
\end{array}$ \\
\hline
\end{tabular}

NOS, not otherwise specified; ${ }^{*} p<0.0001$, medullar carcinoma compared with others histological subtypes; ${ }^{\neq} p<0.01$ compared other ductal carcinoma to other histological subtypes; ${ }^{* *} p<0.01$, compared tubulolobular carcinoma with other histological subtypes; $p<0.05$, compared lobular carcinoma to other histological subtypes. Two-way ANOVA followed by Bonferonni post-test. 
CLINICAL CLASSIFICATION OF THE BREAST CARCINOMA PATIENTS WITH DIFFERENT HISTOLOGICAL SUBTYPES

\begin{tabular}{|c|c|c|c|c|c|c|c|}
\hline Variable & & $\begin{array}{c}\text { Ductal carcinoma, } \\
\text { NOS }\end{array}$ & Medullar & $\begin{array}{c}\text { Others ductal } \\
\text { subtypes }\end{array}$ & Lobular & Tubulo-lobular & Total \\
\hline Stage (AJCC group), & Stage 0 & $3(0.7 \%)$ & 0 & $1(7.7 \%)$ & 0 & 0 & $4(0.71 \%)$ \\
\hline & Stage 1 & $160(37.1 \%)$ & $2(14.3 \%)$ & $7(53.8 \%)$ & $31(38.1 \%)$ & $4(17.4 \%)$ & $204(36.1 \%)$ \\
\hline & Stage 2 & $168(39.2 \%)$ & $9(64.3 \%)$ & $3(23.1 \%)$ & $29(35.7 \%)$ & $10(43.5 \%)$ & $219(39.0 \%)$ \\
\hline & Stage 3 & $96(22.3 \%)$ & $3(21.4 \%)$ & $2(15.4 \%)$ & $20(25 \%)$ & $9(39.1 \%)$ & $130(23.1 \%)$ \\
\hline & Stage 4 & $3(0.7 \%)$ & 0 & 0 & $1(1.2 \%)$ & 0 & $4(0.71 \%)$ \\
\hline & Mean stage & 1.85 & 2.07 & 1.46 & 1.89 & 2.22 & 1.87 \\
\hline AJCC tumour, n (\%) & T0 (is) & $3(0.7 \%)$ & 0 & $1(7.7 \%)$ & 0 & 0 & $4(0.7 \%)$ \\
\hline & $\mathrm{T} 1$ & $209(48.6 \%)$ & $4(28.6 \%)$ & $7(53.8 \%)$ & $36(44.4 \%)$ & $6(26.1 \%)$ & $262(46.7 \%)$ \\
\hline & $\mathrm{T} 2$ & $174(40.5 \%)$ & $10(71.4 \%)$ & $3(23.1 \%)$ & $34(42.0 \%)$ & $14(60.9 \%)$ & $235(41.9 \%)$ \\
\hline & $\mathrm{T} 4$ & $26(6.0 \%)$ & 0 & $2(15.4 \%)$ & $7(8.6 \%)$ & $2(8.7 \%)$ & $37(6.6 \%)$ \\
\hline AJCC Lymph node status, & No & $250(57.9 \%)$ & $7(50.0 \%)$ & $12(92.3 \%)$ & $52(64.2 \%)$ & $7(30.4 \%)$ & $328(59.2 \%)$ \\
\hline$n(\%)$ & N1 & $87(20.3 \%)$ & $4(28.6 \%)$ & 0 & $13(16.1 \%)$ & $9(39.1 \%)$ & $113(18.9 \%)$ \\
\hline & N1mic & $6(1.4 \%)$ & 0 & 0 & 0 & 0 & $6(1.1 \%)$ \\
\hline & $\mathrm{N} 2$ & $62(14.5 \%)$ & $2(14.3 \%)$ & $1(7.7 \%)$ & $10(12.3 \%)$ & $5(21.8 \%)$ & $80(14.2 \%)$ \\
\hline & N3 & $25(5.9 \%)$ & $1(7.1 \%)$ & 0 & $6(7.4 \%)$ & $2(8.7 \%)$ & $34(6.6 \%)$ \\
\hline
\end{tabular}

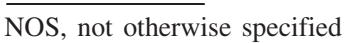

Table 4

HISTOPATHOLOGICAL CHARACTERISTICS OF BREAST CARCINOMA PATIENTS WITH DIFFERENT HISTOLOGICAL SUBTYPES

\begin{tabular}{|c|c|c|c|c|c|c|c|}
\hline Variable & & $\begin{array}{c}\text { Ductal carcinoma, } \\
\text { NOS }\end{array}$ & Medullar & $\begin{array}{c}\text { Others ductal } \\
\text { subtypes }\end{array}$ & Lobular & $\begin{array}{c}\text { Tubulo-lobular } \\
n=23\end{array}$ & Total \\
\hline Molecular subtypes, & Luminal A & $171(39.76 \%)$ & $1(7.14 \%)$ & $8(61.5 \%)$ & $26(11.8 \%)$ & $8(34.78 \%)$ & $214(38.1 \%)$ \\
\hline $\mathrm{n}, \%$ & Luminal B & $159(36.97 \%)$ & $2(14.29 \%)$ & $2(15.4 \%)$ & $47(21.1 \%)$ & $11(47.82 \%)$ & $221(39.4 \%)$ \\
\hline & HER 2+ & $30(6.98 \%)$ & $5(35.71 \%)$ & $1(7.7 \%)$ & $4(9.3 \%)$ & 0 & $40(7.1 \%)$ \\
\hline & Triple negative & $70(16.29 \%)$ & $6(42.86 \%)$ & $2(15.4 \%)$ & $4(4.6 \%)$ & $4(17.40 \%)$ & $86(15.4 \%)$ \\
\hline & Total & $430(100 \%)$ & $14(100 \%)$ & $13(100 \%)$ & $81(100 \%)$ & $23(100 \%)$ & $561(100 \%)$ \\
\hline ER status positive, n (\%) & & $323(75.1 \%)$ & $3(21.4 \%)^{*}$ & $10(76.9 \%)^{\neq}$ & $71(87.7 \%)$ & $18(78.3 \%)$ & $425(75.8 \%)$ \\
\hline PR status positive, $\mathrm{n}(\%)$ & & $289(67.23 \%)$ & $4(28.6 \%)^{*}$ & $8(61.5 \%)$ & $68(84.0 \%)$ & $17(73.9 \%)$ & $386(68.8 \%)$ \\
\hline Ki-67 proliferation index, & $\mathrm{Ki}-67<15 \%$ & $113(50.2 \%)$ & $3(42.9 \%) *$ & $5(71.4 \%)$ & $19(79.2 \%)$ & $4(57.1 \%)$ & $144(25.7 \%)$ \\
\hline$n$ (detected in 270 patients) & $\mathrm{Ki}-67>15 \%$ & $112(49.8 \%)$ & $4(57.1 \%)^{*}$ & $2(28.6 \%)$ & $5(20.8 \%)$ & $3(42.9 \%)$ & $126(22.5 \%)$ \\
\hline (detected in 548 patients) & Grade 2 & $236(56.2 \%)$ & $6(42.9 \%)$ & $4(33.3 \%)$ & $26(32.5 \%)$ & $14(63.6 \%)$ & $286(56.1 \%)$ \\
\hline & Grade 3 & $153(36.4 \%)$ & $8(57.1 \%)$ & $3(25.0 \%)$ & $46(57.5 \%)$ & $8(36.4 \%)$ & $218(36.1 \%)$ \\
\hline
\end{tabular}

${ }^{*} p<0.0001$, compared medullar carcinoma with others histological subtypes; ${ }^{\neq} p<0.01$ compared other ductal carcinoma to other histological subtypes; $* * p<0.01$, compared tubulolobular carcinoma with other histological subtypes; $p<0.05$, compared lobular carcinoma to other histological subtypes. Two way ANOVA followed by Bonferonni post-test.

to other groups. Patients with lobular carcinoma had the lowest risk of sentinel lymph node metastasis, compared to other groups.

Molecular studies of breast cancer revealed biological heterogeneity of the disease and opened new perspectives for personalized therapy. While multiple gene expression-based systems have been developed, current clinical practice is largely based upon conventional clinical and pathologic criteria (Ciriello et al., 2013).

Histological grade, ER-status and histological type is also associated with the patterns and complexity of gene copy number aberrations in breast cancer, with adenoid cystic 
and mucinous carcinomas being examples of ER-negative and ER-positive breast cancers with distinctive repertoires of gene copy number aberrations (Nielsen et al., 2004). In addition, histological grade, ER, PR, and HER2 were found to be the best predictive factors for chemotherapy response in breast cancer (Lips et al., 2013).

Relationship between breast cancer histological and molecular subtypes was demonstrated. In Latvian women, ductal carcinoma, lobular and tubulolobular carcinoma has predominantly luminal A and B subtype, whereas medullar carcinoma had HER2 and TN subtype. However, tubular, cribriform, mucinous, papillary, apocrine carcinomas had predominantly luminal B subtype.

Caldarella et al. (2013) showed that histological type distributions were significantly different between molecular subgroups, and medullary carcinomas tended to be triple negative cancers. In contrast, Ishikawa et al. (2011) showed that medullary carcinoma exhibits not only $\mathrm{TN}$, but also the luminal subtype. Our study demonstrated different distributions of the breast cancer histological and molecular subtypes compared to other countries. Our findings support Ishikawa et al. (2011) data, that medullary carcinoma exhibits not only TN, but also the luminal B subtype.

Thus, our data support recent evidence that breast cancer subtypes are distributed in a specific pattern corresponding to country, race or ethnicity (Goldrich et al., 2011). Other authors have shown that luminal B tumours are the most frequent molecular subtype in breast cancer of North African women, whereas in most European countries and USA the most common molecular subtype is luminal A (Weigelt et al., 2010; El Fatemi et al., 2012; Ng et al., 2102; Dreyer et al., 2013).

Our study showed that triple negative breast cancer predominantly had the medullar carcinoma histology; however, TN subtype is observed also in some ductal carcinoma of NOS subtype, lobular carcinoma, tubulolobular carcinoma and other histological subtypes. It has been recently demonstrated that TN cancer is a non-uniform disease. Different histological subtypes have different age distribution and behaviour (Dreyer et al., 2013; Montagna et al., 2013). Our study supports these findings demonstrating that the TN subtype is characteristic not only for medullar carcinoma, but to a lesser extent also for other histological forms.

\section{ACKNOWLEDGEMENTS}

The study was supported by the European Social Fund within the project "Support for Doctoral Studies at University of Latvia”.

\section{REFERENCES}

Bhargava, R., Striebel, J., Beriwal, S., Flickinger, J. C., Onisko, A., Ahrendt, G., Dabbs, D. J. (2009). Prevalence, morphologic features and proliferation indices of breast carcinoma molecular classes using immunohistochemical surrogate markers. Int. J. Clin. Exp. Pathol., 2, 444-455.
Cadoo, K. A., Traina, T. A., King, T. A. (2013). Advances in molecular and clinical subtyping of breast cancer and their implications for therapy. Surg. Oncol. Clin. N. Amer., 22 (4), 823-840.

Caldarella, A., Buzzoni, C., Crocetti, E., Bianchi, S., Vezzosi, V., Apicella, P., Biancalani, M., Giannini, A., Urso, C., Zolfanelli, F., Paci E. (2013). Invasive breast cancer: A significant correlation between histological types and molecular subgroups. J. Cancer Res. Clin. Oncol., 139 (4), 617-623.

Carey, L. A., Perou, C. M., Livasy, C. A., Dressler, L. G., Cowan, D., Conway K, Karaca G., Troester, M. A., Tse, C. K., Edmiston, S., Deming, S. L., Geradts, J., Cheang, M. C., Nielsen, T. O., Moorman, P. G., Earp, H. S., Millikan, R. C. (2006). Race, breast cancer subtypes, and survival in the Carolina Breast Cancer Study. JAMA (Journal of the American Medical Association), 295, 2492-2502.

Chekhun, S., Bezdenezhnykh, N., Shvets, J., Lukianova, N. (2013). Expression of biomarkers related to cell adhesion, metastasis and invasion of breast cancer cell lines of different molecular subtype. Exp. Oncol., 35 (3), 174-179.

Ciriello, G., Sinha, R., Hoadley, K. A., Jacobsen, A S., Reva, B., Perou, C. M., Sander, C., Schultz, N. (2013). The molecular diversity of Luminal A breast tumors. Breast Cancer Res. Treat., 41 (3), 409-420.

Desmedt, C., Sotiriou C. (2006). Proliferation: The most prominent predictor of clinical outcome in breast cancer. Cell Cycle, 5 (19), 2198-2202.

Dreyer, G., Vandorpe, T., Smeets, A., Forceville, K., Brouwers, B., Neven, P., Janssens, H., Deraedt, K., Moerman, P, Van Calster, B., Christiaens, M. R., Paridaens, R., Wildiers H. (2013). Triple negative breast cancer: Clinical characteristics in the different histological subtypes. Breast, 22 (5), 761-766.

El Fatemi, H., Chahbouni, S., Jayi, S., Moumna, K., Melhouf, M. A., Bannani, A., Mesbahi, O., Amarti, A. (2012). Luminal B tumors are the most frequent molecular subtype in breast cancer of North African women: An immunohistochemical profile study from Morocco. Diagn. Pathol., 7, 170 .

Edge, S. E., Byrd, D. R., Compton, C. C., Fritz A. G., Green, F. L., Frotti, A. (eds.) (2010). AJCC (American Joint Committee on Cancer) Cancer Staging Manual, $7^{\text {th }}$ edition. New York: Springer. 649 pp.

Goldhirsch, A., Wood, W. C., Coates, A. S., Gelber, R. D., Thürlimann, B., Senn, H. J. (2011). Strategies for subtypes dealing with the diversity of breast cancer: highlights of the St. Gallen International Expert Consensus on the Primary Therapy of Early Breast Cancer. Ann. Oncol., 22 (8), 1736-1747.

Ishikawa, Y., Horiguchi, J., Toya, H., Nakajima, H., Hayashi, M., Tagaya, N., Takeyoshi, I., Oyama, T. (2011). Triple-negative breast cancer: Histological subtypes and immunohistochemical and clinicopathological features. Cancer Sci., 102 (3), 656-662.

Lakhani, S. R., Ellis, I. O., Schnitt, S. J., Tan, P. H., van de Vijver, M. J. (eds) (2012). WHO Classification of Tumours of the Breast, Fourth Edition. International Agency for Research on Cancer. 500 pp.

Laurinavicius, A., Laurinaviciene, A., Ostapenko, V., Dasevicius,D., Jarmalaite, S., Lazutka, J. (2012). Immunohistochemistry profiles of breast ductal carcinoma: Factor analysis of digital image analysis data. Diagn. Pathol., 7, 2-27.

Lips, E. H., Mulder, L., de Ronde, J. J., Mandjes, I. A., Koolen, B. B., Wessels, L. F., Rodenhuis, S., Wesseling, J. (2013). Breast cancer subtyping by immunohistochemistry and histological grade outperforms breast cancer intrinsic subtypes in predicting neoadjuvant chemotherapy response. Breast Cancer Res. Treat., 140 (1), 63-71.

Montagna, E., Maisonneuve, P., Rotmensz, N., Cancello, G., Iorfida, M., Balduzzi, A., Galimberti, V., Veronesi, P., Luini, A., Pruneri, G., Bottiglieri, L., Mastropasqua, M. G., Goldhirsch, A., Viale, G., Colleoni, M. (2013). Heterogeneity of triple-negative breast cancer: Histologic subtyping to inform the outcome. Clin. Breast Cancer, 13 (1), 31-39.

Nielsen, T. O., Hsu, F. D., Jensen, K., Cheang, M., Karaca, G., Hu, Z., Hernandez-Boussard, T., Livasy, C., Cowan, D., Dressler, L., Akslen, L. 
A., Ragaz, J., Gown, A. M., Gilks, C. B., van de Rijn M., Perou, C. M. (2004). Immunohistochemical and clinical characterization of the basal-like subtype of invasive breast carcinoma. Clin. Cancer Res., 10, 5367-5374.

Ng, C., Weigelt, B., Grigoriadis, A., Reis-Filho, J. S. (2012). Prognostic signatures in breast cancer: Correlation does not imply causation. Breast Cancer Res., 14 (3), 313.

Perou, C. M., Sorlie, T., Eisen, M. B., Rijn M van de, Jeffrey, S. S., Rees, C. A., Pollack, J. R., Ross, D. T., Johnsen, H., Akslen, L. A., Fluge, O., Pergamenschikov, A., Williams, C., Zhu, S. X., Lønning, P. E.,

Received 13 December 2013
Børresen-Dale, A. L., Brown, P. O., Botstein, D. (2000). Molecular portraits of human breast tumours. Nature, 406, 747-752.

Srebnij, A., Ancans, G., Eglitis, J., Krumins, V., Graudina, L., Berzins, J., Vikmanis, U. (2011). Development of Breast-conserving surgery in breast cancer treatment in Latvia (Last 20 years experience at Latvian Oncology Centre). Acta Chirurgica Latviensis, 11, 21-27.

Weigelt, B., Geyer, F. C., Reis-Filho, J. S. (2010). Histological types of breast cancer: How special are they? Mol. Oncol., 4 (3), 192-208.

Weigelt, B., Horlings, H. M., Kreike, B., Hayes, M. M., Hauptmann, M., Wessels, L. F., de Jong, D., Van de Vijver, M. J., Van't Veer, L. J., Peterse, J. L. (2008). Refinement of breast cancer classification by molecular characterization of histological special types. J. Pathol., 216 (2), 141-150.

\section{PIENA DZIEDZERA AUDZĒJA HISTOLOG̣ISKO APAKŠTIPU IZPLATĪBA SAISTĪBĀ AR KLĪNISKIEM UN PATOLOG̦ISKIEM RĀDĪTĀJIEM}

Piena dziedzera audzējs ir heterogēna slimība, kas sastāv no vairākām histoloǵiskām formām, kurām ir raksturīga noteikta morfoloğiskā un imūnhistoḳīmiskā aina. Mūsu pētījuma mērḳis bija novērtēt piena dziedzera audzēja histoloğiskos un molekulāros apakštipus un to saistību ar klīniskajiem un histopatoloğiskajiem rādītājiem. Pētījumā tika iekḷauta 561 paciente, kas tika operētas sakarā ar piena dziedzera audzēju laika posmā no 2003. gada janvāra līdz 2012. gada decembrim. Invazīiā nespecifiskā tipa duktālā karcinoma konstatēta 430 pacientēm (76,65\% gadījumu), medulārā karcinoma tika novērota 14 pacientēm $(2,45 \%$ gadījumu), 81 pacientei (14,4\%) novērota lobulāra karcinoma, bet 23 pacientēm (4,19\% gadījumu) tika novērota tubulolobulārā karcinoma. Savukārt, reti specifiski duktālās karcinomas apakštipi tika novēroti 13 pacientēm (2,31\% gadījumu). Duktālā carcinoma, lobulārā un tubulolobulārā karcinoma pārsvarā bija lumināla A un B apakštipa audzēji, bet medulārā karcinoma bija TN (trīskārši negatīva) un HER2-apakštipa. Savukārt, tubulārā, kribriforma, mucinozā, papilārā un apokrīna karcinoma bija luminālā A apakštipa audzēji. Darbā tika novērota korelācija starp audzēja histoloğisko un molekulāro apakštipu. Mūsu pētījums pirmo reizi parāda piena dziedzera audzēja histoloğisko un molekulāro apakštipu sastopamību Latvijas sievietēm un to saistību ar klīniskajiem un histopatoloğiskajiem rādītājiem. 